Азиатско-Тихоокеанский регион: экономика, политика, право. 2021. Т. 24, № 4. С. 72-88.

Pacific Rim: Economics, Politics, Law. 2021. V. 24, No 4. P. 72-88.

\title{
ЭКОНОМИКА
}

Научная статья

УДК 658:656.2.02:005.5

https://doi.org/10.24866/1813-3274/2021-4/72-88

\section{МЕТОДИКА КОМПЛЕКСНОЙ ОЦЕНКИ ТРАНСПОРТНОЙ ОРГАНИЗАЦИИ КАК ИНСТРУМЕНТ БИЗНЕС-ПЛАНИРОВАНИЯ ЕЁ СТРАТЕГИЧЕСКОГО РАЗВИТИЯ}

\section{Чеченова Лиана Мухамедовна}

Петербургский государственный университет путей сообщения Императора Александра I; 190031, Россия, Санкт-Петербург, Московский пр., д. 9; liana1981-149@mail.ru; https://orcid.org/0000-0002-2641-9454; AAU-8100-2021

Аннотация. В современных условиях возрастают требования к повышению эффективности принятия управленческих решений организаций с государственным участием. Это предопределяет высокую значимость проводимого исследования. Цель исследования: анализ финансовых показателей и последующая комплексная оценка финансово-хозяйственной деятельности организации в сфере пассажирских железнодорожных перевозок дальнего следования по методологии, учитывающей стратегический характер деятельности. Meтоды: использованы методы финансового анализа, экономико-математического моделирования. Результаты: определены перспективные направления деятельности транспортной организации по бизнес-блокам. Систематизированы методологические основы оценки финансовой устойчивости применительно к проводимому исследованию, основным назначением каждой из методик финансовой оценки является мониторинг показателей в динамике и получение объективного результата в части финансово-экономического положения организации. Сформирована методологическая основа, позволяющая в полном объёме оценить текущее финансовое состояние организации, что способствует дальнейшей разработке предложений по повышению эффективности её деятельности. Предложены и обоснованы практические мероприятия с опорой на фактор стратегической направленности деятельности транспортной организации, способствующие повышению её платёжеспособности, ликвидности и финансовой устойчивости. Приведены результаты

(C) Чеченова Л. М., 2021 
оценки по итогам комплексного анализа деятельности и расчёта необходимых показателей. Практическая цуенность: заключается в перспективах применения её ключевых результатов при альтернативной оценке финансового состояния с целью повышения эффективности функционирования транспортной организации. Сформированный методологический каркас может быть использован для критического анализа, мониторинга и дальнейшей оценки деятельности транспортных систем.

Ключевые слова: финансово-хозяйственная деятельность, транспортная организация, пассажирские железнодорожные перевозки, перспективные направления деятельности, методологические основы оценки, финансовый анализ, оценка результатов, реализация стратегических ориентиров.

Для циитирования: Чеченова Л. М. Методика комплексной оценки транспортной организации как инструмент бизнес-планирования её стратегического развития // Азиатско-Тихоокеанский регион: экономика, политика, право. 2021. Т. 24, № 4. С. 72-88. https://doi.org/10.24866/1813-3274/2021-4/72-88.

\title{
ECONOMICS
}

Original article

\section{METHODS OF COMPREHENSIVE ASSESSMENT \\ OF A TRANSPORT ORGANIZATION AS A BUSINESS PLANNING TOOL FOR ITS STRATEGIC DEVELOPMENT}

\author{
Liana M. Chechenova, \\ St. Petersburg State University of Railways of Emperor Alexander I, \\ 190031, Russia, St. Petersburg, Moskovsky Ave., 9; liana1981-149@mail.ru; \\ https://orcid.org/0000-0002-2641-9454, AAU-8100-2021
}

Abstract. In modern conditions, the requirements for improving the efficiency of managerial decision-making of organizations with state participation are increasing. This determines the high significance of the conducted research. Objective: analysis of financial indicators and subsequent comprehensive assessment of the financial and economic activities of the organization in the field of long-distance passenger rail transportation using a methodology that takes into account the strategic nature of the activity. Methods: methods of financial analysis, economic and mathematical modeling were used. Results: the promising areas of activity of the transport organization by business blocks are determined. The methodological foundations of the assessment of financial stability in relation to the conducted research are systematized, the main purpose of each of the methods of financial assessment is to monitor the indicators in the dynamics and obtain an objective 
result in terms of the financial and economic situation of the organization. A methodological basis has been formed that allows us to fully assess the current financial condition of the organization, which contributes to the further development of proposals to improve the efficiency of its activities. Practical measures are proposed and justified based on the factor of strategic orientation of the transport organization's activities, which contribute to increasing its solvency, liquidity and financial stability. The results of the assessment based on the results of a comprehensive analysis of the activity and the calculation of necessary indicators are presented. Practical importance: it consists in the prospects of applying its key results in an alternative assessment of the financial state in order to improve the operational efficiency of a transport organization. The formed methodological framework can be used for critical analysis, monitoring and further evaluation of the activities of transport systems.

Keywords: financial and economic activity, transport organization, passenger rail transportation, promising areas of activity, methodological bases of assessment, financial analysis, evaluation of results, implementation of strategic guidelines.

For citing: Chechenova L. M. Methods of comprehensive assessment of a transport organization as a business planning tool for its strategic development // PACIFIC RIM: Economics, Politics, Law. 2021. T. 24, No. 4. P. 72-88. https://doi.org/10.24866/18133274/2021-4 /72-88.

\section{Введение}

На современном этапе развития наблюдается рост требований к повышению эффективности и результативности управленческих решений для организаций с государственным участием. Это усиливает значение анализа финансовой устойчивости в управлении их деятельностью. Основным инструментом оценки финансового состояния и бизнес-планирования устойчивого роста является финансовый анализ, который даёт возможность объективно оценить существующее состояние организации с учётом внутренних и внешних факторов (рис. 1).

На практике используются различные методы и инструменты анализа и оценки финансового состояния. В каждом конкретном случае их выбор определяется целями и задачами организационного развития [1, с. 467].

За последние годы значительно претерпела изменения сущность транспортных систем в целом и, прежде всего, сферы железнодорожного транспорта. Это связано с масштабным социальным, технологическим и экономическим сдвигом на рынке транспортных услуг, формируемым новой моделью потребления. Появляются новые рынки товаров и услуг, разрушаются и модифицируются старые. Существенно меняются география, структура и виды перевозок. Это приводит к необходимости проведения на регулярной основе финансового анализа для того, чтобы иметь объективную информацию, 
оценивать хозяйственные и финансовые результаты, разрабатывать стратегические мероприятия по повышению эффективности.

\section{Внешние}

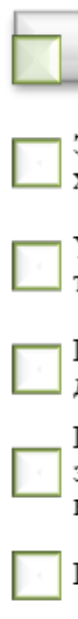
технологий

\section{Внутренние}

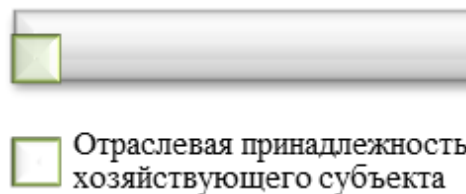

Структура выпускаемой продукции (услуги), её доля в общем платежеспособном спросе

Уровень развития техники и

Платёжеспособный спрос и уровень доходов потребителей

Налоговая политика и законодательные акты, контролирующие деятельность

Внешнеэкономические связи
Размер оплаченного уставного капитала

Величина издержек, их динамика в сравнении с денежными расходами Состояние имущества и финансовых ресурсов, включая запасы и резервы; их состав и структура

Puc. 1. Факторы изменения финансового состояния организации.

Составлено автором на основе собственных выводов и заключений

Fig. 1. Factors of changes in the financial condition of the organization.

Compiled by the author based on her own findings and conclusions

\section{Методология исследования}

Цель исследования состоит в проведении комплексной оценки финансовохозяйственной деятельности организации, осществляющей деятельность в сфере пассажирских железнодорожных перевозок дальнего следования, с учётом стратегического характера деятельности компании. Объектом исследования является финансово-экономическая деятельность АО «Федеральная пассажирская компания» (далее по тексту - АО «ФПК») за период 2018-2020 гг. Материалами исследования послужили отраслевая нормативно-правовая документация, аналитические материалы и статистичекая отчётность организации [2].

Для определения уровня эффективности функционирования АО «ФПК» и реализации стратегических важных целей организации применяется система ключевых показателей эффективности, утвержденных Советом директоров АО «ФПК» 2 июля 2020 г. Показатели, включённые в данный реестр, представлены на рис. 2.

Динамика приведенных показателей свидетельствует о значительном ухудшении результататов в 2020 г., что вызвано сокращением транспортной мобильности пассажиров и снижением пассажирооборота в связи с эпидемиологической обстановкой и ограничительными мерами, вызванными Covid-19-20. 


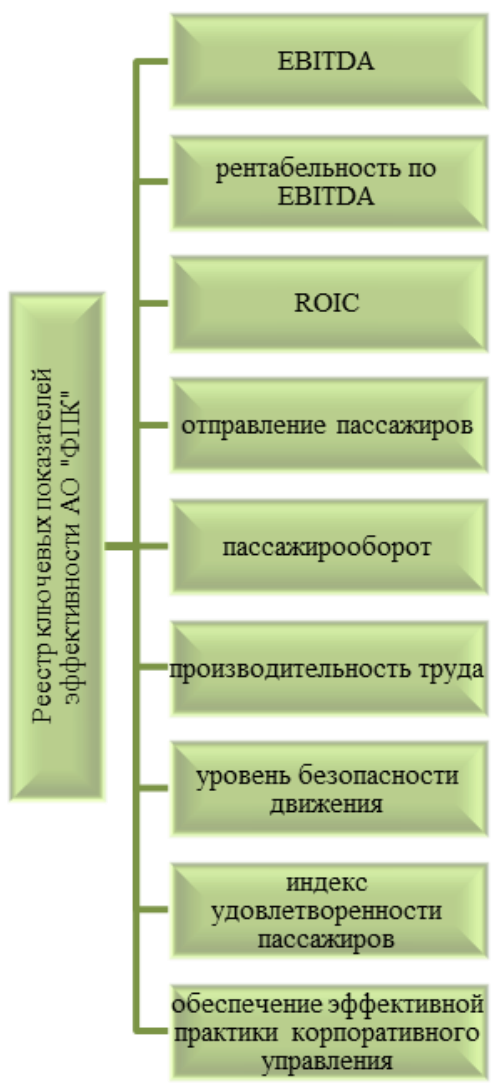

Puс. 2. Система ключевых показателей эффективности АО «ФПК» Составлено автором на основе [2]

Fig. 2. The system of key performance indicators of JSC «FPC» Compiled by the author based on [2]

Таблицฺа 1

Ключевые показатели эффективности АО «Федеральная пассажирская компания» Key performance indicators JSC «Federal Passenger Company»

\begin{tabular}{|l|l|l|l|}
\hline Показатели эффективности & 2018 г. & 2019 г. & 2020 г. \\
\hline ЕВІТDА с учетом субсидий, \% & 26,8 & 29,6 & $-22,9$ \\
\hline Рентабельность по ЕВІТDА с учётом субсидий, \% & 11,4 & 12,1 & $-16,7$ \\
\hline Пассажирооборот, млрд пасс.-км & 91,6 & 93,6 & 48,2 \\
\hline Перевезённые пассажиры, млн пасс. & 102,0 & 108,0 & 59,0 \\
\hline Производительность труда, тыс. пасс.-км/чел. & 1628 & 1670 & 980 \\
\hline Индекс удовлетворённости пассажиров, 1-5 балл. & 4,22 & 4,33 & 4,40 \\
\hline Эффективность корпоративного управления, \% & - & - & 97 \\
\hline
\end{tabular}

Составлено автором на основе [2]. Compiled by the author based on [2] 
По основным производственным показателям в сравнении с 2019 г. наблюдается снижение объёма перевезённых пассажиров на $59 \%$, уровня пассажирооборота на $53 \%$, в т.ч. за счёт международного сообщения на $82 \%$. Показатель производительности труда уменьшился лишь на $41 \%$, что связано с корпоративной политикой организации, делающей упор на сохранение квалифицированного контингента при существенном снижении объёма работ. Финансовые результаты также имеют тенденцию к снижению: их уровень по доходам от пассажирских перевозок сократился на $54 \%$, по доходам от прочих видов деятельности (ремонт и обслуживание подвижного состава, сервисное обслуживание, аренда и т.д.) - почти на 70\%. Тем не менее, АО «ФПК» удалось осуществить антикризисные меры, связанные со сглаживанием кризисных последствий, а именно:

- сохранение стратегически и социльно значимых маршрутов за счёт объединения, сокращения периодичности и приостановления многовариантных маршрутов;

- поддержка ключевого контингента за счёт привлечения краткосрочных заёмных средств для выполнения обязательств перед сотрудниками; за счёт сокращения мотивационных выплат управленческому персоналу и исключения командировок;

- дополнительная эмиссия ценных бумаг на 20 млрд руб. в целях дальнейшей реализации стратегически значимой долгосрочной программы по закупке и обновлению подвижного состава;

- изменение структуры долга по покрытию услуг локомотивной тяги и инфраструктуры в общей сложности на 17 млрд руб.

Заметим, что несмотря на общую тенденцию сокращения пассажирских перевозок, объёмы перевозок багажа, грузобагажа и почты в 2020 г. соответствуют объёмам 2019 г.

\section{Результаты исследования}

1. Определены перспективные направления деятельности транспортной организации по бизнес-блокам (рис. 3).

На фоне активного роста авиаперевозок, увеличения доли личного автотранспорта, развития логистических сервисов по коллективному использованию транспортных средств, улучшения дорожного хозяйства железнодорожный перевозчик перестаёт доминировать на рынке пассажирских перевозок дальнего следования, что наглядно представлено на рис. 4.

Тем не менее, АО «ФПК» по-прежнему сохраняет лидерство по пассажирской мобильности в РФ, что подтверждается цифрами: маршрутная сеть покрывает 77 регионов РФ (из 85), доля Компании по пассажирообороту в дальнем следовании составляет более $90 \%$ в общей струткуре перевозок железнодорожным транспортом, наличие крупнейшего парка современного подвижного состава в 16,6 тыс. вагонов и 475 пар поездов обеспечивает мобильность для различных категорий пассажиров [3, с. $65 ; 4$, с. 284]. 


\begin{tabular}{|c|c|c|c|}
\hline $\begin{array}{l}\text { Государство: } \\
\text { Регулирование, субсидиро- } \\
\text { вание в транспортной по- } \\
\text { движности населения; } \\
\text { Повышение инвестицион- } \\
\text { ной привлекательности } \\
\text { транспортной отрасли; } \\
\text { Повышение бюджетной } \\
\text { эффективности транспорта. }\end{array}$ & $\begin{array}{l}\text { Виды бизнеса: } \\
\text { Перевозка пасса- } \\
\text { жиров в дальнем } \\
\text { следовании в регу- } \\
\text { лируемом сегмен- } \\
\text { те; } \\
\text { Перевозка пасса- } \\
\text { жиров в междуна- } \\
\text { родном сообщении. }\end{array}$ & \multirow{2}{*}{$\begin{array}{l}\text { Продуктовый ряд: } \\
\text { Перевозка в поез- } \\
\text { дах: } \\
\text { • фирменных; } \\
\text { • нефирменных; } \\
\text { - международных; } \\
\text { • туристических. } \\
\text { Прочее } \\
\text { Перевозка багажа, } \\
\text { грузобагажа; } \\
\text { Оказание дополни- } \\
\text { тельных сервисных } \\
\text { услуг; } \\
\text { Прочие виды услуг. }\end{array}$} & \multirow{2}{*}{$\begin{array}{l}\text { Доминантные } \\
\text { ценности: } \\
\text { Для пассажиров: } \\
\text { • безопасное, ком- } \\
\text { фортное перемещение; } \\
\text { • интересное время- } \\
\text { провождение; } \\
\text { • экономия времени. } \\
\text { Для государства: } \\
\text { • увеличение транс- } \\
\text { портной подвижности } \\
\text { населения. } \\
\text { Для корпоративных кли- } \\
\text { ентов и потребителей: } \\
\text { • высокое качество } \\
\text { услуг. }\end{array}$} \\
\hline $\begin{array}{l}\text { Базовые ресурсы: } \\
\text { • } \quad \text { Среднесписочная чис- } \\
\text { ленность - } 53 \text { тыс. чел; } \\
\text { • } \quad \text { Вагонный парк - } 16,6 \\
\text { тыс. вагонов; } \\
\text { • } \quad \text { Вагонооборот - } 1949 \\
\text { млн ваг-км }\end{array}$ & $\begin{array}{l}\text { Бизнес-модель АO } \\
\text { «ПК» }\end{array}$ & & \\
\hline $\begin{array}{l}\text { Состав расходов (оптими- } \\
\text { защия), млрд руб.: } \\
\text { Пассажирские перевозки - } \\
181,5 . \\
\text { Прочие виды деят. - } 169,0 . \\
\text { Инвестиционные расходы: } \\
\text { Приобретение подвижного } \\
\text { состава; } \\
\text { Модернизация подвижного } \\
\text { состава; } \\
\text { Программа информатизации. }\end{array}$ & $\begin{array}{l}\text { Состав доходов, } \\
\text { млрд руб.: } \\
\text { Доходы итого - } \\
130,9 . \\
\text { Пассажирские пе- } \\
\text { ревозки - } 114,6 . \\
\text { Прочие виды дея- } \\
\text { тельности - 16,3. }\end{array}$ & $\begin{array}{l}\text { Основные партнё- } \\
\text { ры: } \\
\text { ОАО «РЖД»; } \\
\text { Росжелдорснаб; } \\
\text { Пригородные пас- } \\
\text { сажирские компа- } \\
\text { нии. }\end{array}$ & $\begin{array}{l}\text { Потребители транс- } \\
\text { портной услуги по } \\
\text { перевозке: } \\
\text { Пассажиры; } \\
\text { Корпоративные клиен- } \\
\text { ты; } \\
\text { Другие потребители; } \\
\text { Органы государствен- } \\
\text { ной власти и ведом- } \\
\text { ства. }\end{array}$ \\
\hline
\end{tabular}

Puc. 3. Перспективные направления деятельности АО «ФПК» по бизнес-блокам. Составлено автором на основе собственных выводов и заключений

Fig. 3. Promising areas of activity of JSC «FPC» by business blocks.

Compiled by the author based on her own findings and conclusions

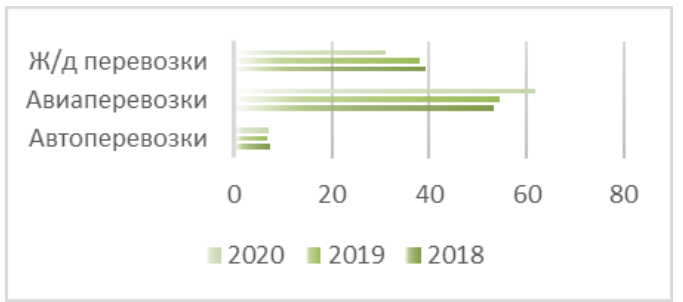

Puc. 4. Доля перевозчиков в структуре пассажирооборота в дальнем следовании, \%. Составлено автором на основе [2]

Fig. 4. The share of carriers in the structure of long-distance passenger traffic, $\%$. Compiled by the author based on [2]

2. Систематизированы методологические основы оценки финансовой устойчивости применительно к проводимому исследованию (рис. 5). Основным назначением каждой из методик финансовой оценки является мониторинг показателей в динамике и получение объективного результата в части финансово-экономического положения организации. 
Чеченова Л. М. Методика комплексной оценки транспортной организации как инструмент бизнес-планирования её стратегического развития
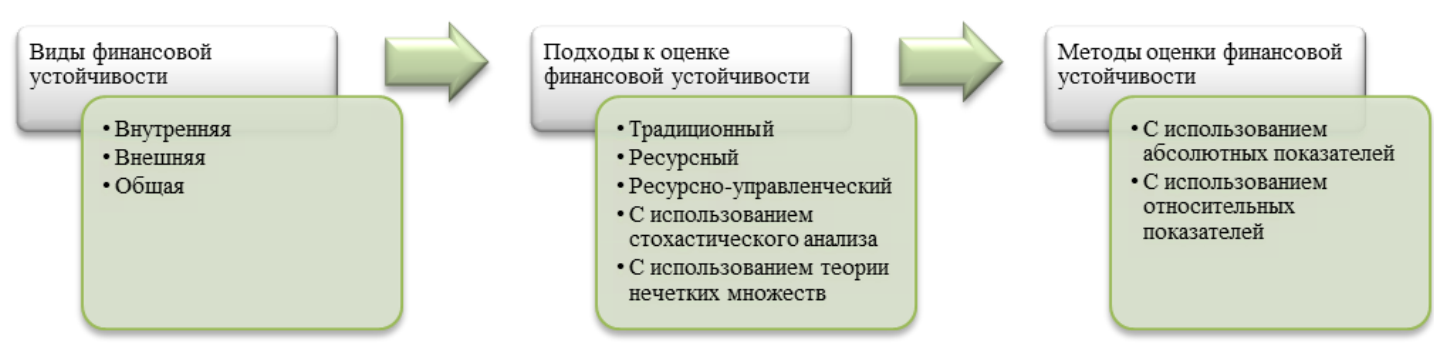

Puc. 5. Систематизация методологических основ оценки финансовой устойчивости. Составлено автором на основе собственных выводов и заключений

Fig. 5. Systematization of the methodological foundations of financial stability assessment. Compiled by the author based on her own findings and conclusions

Принимая во внимание отраслевую специфику АО «ФПК», необходимо отметить определённые сложности её хозяйственной деятельности в 2019-2020 гг., Пандемический кризис создал определённые трудности в выборе конкретной методики и определённого показателя в качестве конечного и независимого.

Проведём обзор существующих исследований в области финансового анализа организаций. Исследованиями в области анализа и мониторинга финансовохозяйственной деятельности занимались такие авторы, как У. Бивер, Э. Альтман, Д. Дюран, Т. В. Погодина, А. Д. Шеремет, Р. С. Сайфуллин и Г. Г. Кадыков, Л. В. Донцова и Н. А. Никифорова и многие другие. При этом модель Бивера и двухфакторная модель Альтмана ориентируются на вероятностную оценку финансовой несостоятельности, где значительный акцент делается на долю собственных источников в формировании активов, а в качестве исходных данных используются стандарты финансовой отчётности западных компаний, что влияет на существенные различия в расчётных коэффициентах [5, с. 308]. Кредитный скоринговый анализ Дюрана предполагает сравнительный рейтинг организаций по текущему состоянию финансовой устойчивости. Алгоритм оценки Шеремета на практике не ограничивает количество показателей и организаций, что применимо исключительно для сравнительного рейтинга компаний с аналогичными видами деятельности. Методика оценки Донцовой-Никифоровой также даст необъективный результат, поскольку авторами не учитывается длительный характер кредитования по займам, предоставляемым для обеспечения перевозки пассажиров в регулируемом сегменте при том, что уровень просроченной задолженности АО «ФПК» по итогам 2019 г. составил 0,02\%, 2020 г. - 0,03\%, что подтверждает высокую степень платёжной дисциплины в части обеспечения обязательств.

3. Сформирована методологическая основа, позволяющая в полном объёме оценить текущее финансовое состояние организации, что способствует дальнейшей разработке предложений по повышению эффективности её деятельности. 
Действие 1. Анализ показателей платёжеспособности организации, представленный на рис. 6.

Абсолютная ликвидность

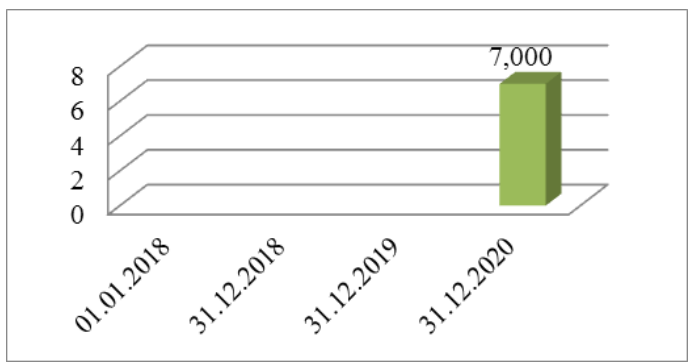

Текущая ликвидность

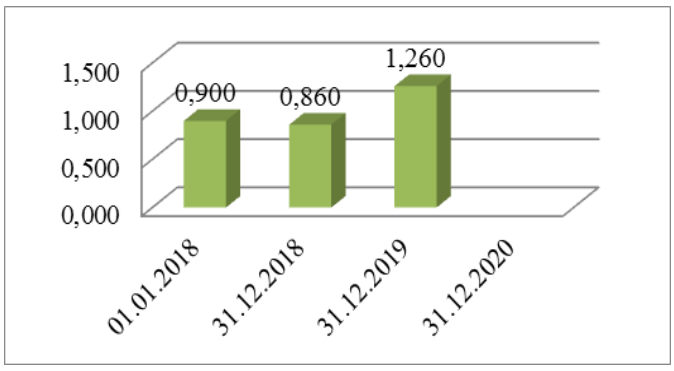

Критическая ликвидность

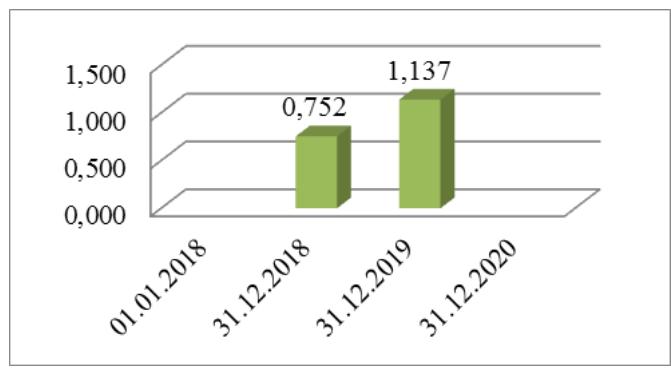

Общая ликвидность

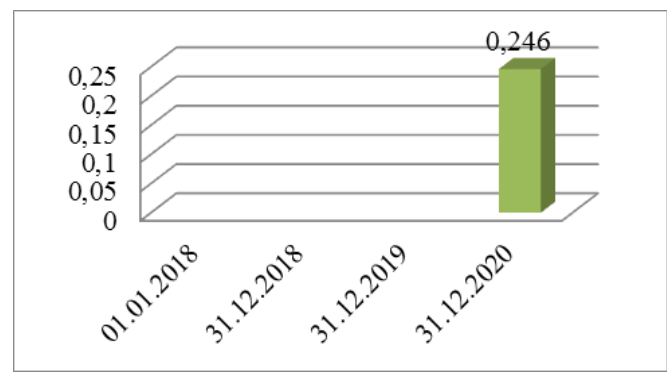

Pис. 6. Динамика коэффициентов ликвидности АО «ФПК» за 2018-2020 гг.

Составлено автором на основе [2]

Fig. 6. Dynamics of the liquidity ratios of JSC «FPC» for 2018-2020.

Compiled by the author based on [2]

Результаты расчётов говорят о критическом состоянии коэффициента ликвидности в 2020 г., что обусловленно сокращением имеющихся у Компании краткосрочных финансовых вложений, а также увеличением краткосрочных обязательств, скорее всего это связано с нестабильной экономической ситуацией в стране, а также низким спросом на пассажирские перевозки.

Действие 2. Оценка финансовой устойчивости АО «ФПК» с применением абсолютных и относительных показателей деятельности, структурирование и расчётные результаты по которым представлены в табл. 2.

Анализ финансовой устойчивости АО «ФПК» с помощью абсолютных показателей выявил определённые признаки, свидетельствующие о кризисном финансовом состоянии. Для финансирования запасов возникла необходимость привлечения кредиторской задолженности. К 2019 г. видим относительную стабильность. В 2020 г. для смягчения кризисного состояния привлечён долгосрочный займ. 
Абсолютные и относительные показатели деятельности

Absolute and relative performance indicators

\begin{tabular}{|c|c|c|c|c|c|c|c|}
\hline $\begin{array}{c}\text { Абсолютные } \\
\text { показатели, млн руб. }\end{array}$ & 2018 г. & 2019 г. & 2020 г. & $\begin{array}{c}\text { Относительные } \\
\text { показатели, д.ед. }\end{array}$ & 2018 г. & 2019 г. & 2020 г. \\
\hline $\begin{array}{l}\text { 1. Капитал } \\
\text { и резервы }\end{array}$ & 201190,7 & 222817,1 & 206559,6 & $\begin{array}{l}\text { 1. Коэффициент } \\
\text { автономии }\end{array}$ & 0,774 & 0,717 & 0,640 \\
\hline $\begin{array}{l}\text { 2. Внеоборотные } \\
\text { активы }\end{array}$ & 248265,3 & 266357,2 & 289880,2 & $\begin{array}{l}\text { 2. Коэффициент } \\
\text { финансовой зависимости }\end{array}$ & 0,287 & 0,283 & 0,360 \\
\hline $\begin{array}{l}\text { 3. Собственные } \\
\text { оборотные средства }\end{array}$ & $-47074,6$ & $-43540,2$ & $-83320,7$ & $\begin{array}{l}\text { 3. Коэффициент } \\
\text { соотношения заёмных } \\
\text { и собственных средств }\end{array}$ & 0,402 & 0,395 & 0,562 \\
\hline $\begin{array}{l}\text { 4. Долгосрочные } \\
\text { кредиты }\end{array}$ & 38677,5 & 49213,5 & 48500,0 & $\begin{array}{l}\text { 4. Коэффициент } \\
\text { финансовой устойчивости }\end{array}$ & 0,866 & 0,891 & 0,794 \\
\hline $\begin{array}{l}\text { 5. Наличие } \\
\text { собственных } \\
\text { и долгосрочных } \\
\text { источников }\end{array}$ & $-8397,5$ & 5673,4 & $-34820,7$ & $\begin{array}{l}\text { 5. Доля краткосрочных } \\
\text { кредитов и займов в } \\
\text { заёмных средствах }\end{array}$ & 0,091 & 0,015 & 0,137 \\
\hline $\begin{array}{l}\text { 6. Краткосрочные } \\
\text { кредиты }\end{array}$ & 7369,3 & 1304,8 & 15888,4 & $\begin{array}{l}\text { 6. Доля расчётов } \\
\text { с кредиторами в заёмных } \\
\text { средствах }\end{array}$ & 0,307 & 0,309 & 0,394 \\
\hline $\begin{array}{l}\text { 7. Наличие } \\
\text { основных } \\
\text { источников }\end{array}$ & $-1028,3$ & 6978,2 & $-18932,3$ & $\begin{array}{l}\text { 7. Коэффициент соотношения } \\
\text { мобильных } \\
\text { и иммобилизованных средств }\end{array}$ & 0,130 & 0,160 & 0,107 \\
\hline 8. Запасы & 3857,3 & 3780,5 & 44736 & $\begin{array}{l}\text { 8. Коэффициент } \\
\text { маневренности }\end{array}$ & $-0,234$ & $-0,195$ & $-0,403$ \\
\hline $\begin{array}{l}\text { 9. Излишек (+) или } \\
\text { дефицит (-) собствен- } \\
\text { ных оборотных } \\
\text { средств для формиро- } \\
\text { вания запасов } \Delta \text { СОС }\end{array}$ & $-50931,9$ & $-47320,7$ & $-87794,3$ & $\begin{array}{l}\text { 9. Коэффициент } \\
\text { обеспеченности оборотных } \\
\text { активов собственными } \\
\text { оборотными средствами }\end{array}$ & $-1,449$ & $-1,017$ & $-2,663$ \\
\hline $\begin{array}{l}\text { 10. Излишек (+) или } \\
\text { дефицит (-) соб- } \\
\text { ственных и долго- } \\
\text { срочных источников } \\
\text { для формирования } \\
\text { запасов } \Delta \text { СДИ }\end{array}$ & $-12254,8$ & 1892,9 & $-39294,3$ & $\begin{array}{l}\text { 10. Коэффициент } \\
\text { обеспеченности запасов } \\
\text { собственными оборотными } \\
\text { средствами }\end{array}$ & $-12,204$ & $-11,517$ & $-18,625$ \\
\hline $\begin{array}{l}\text { 11. Излишек (+) или } \\
\text { дефицит (-) основ- } \\
\text { ных источников для } \\
\text { формирования запа- } \\
\text { сов } \Delta \text { ОИ }\end{array}$ & $-4885,55$ & 3197,7 & $-23405,0$ & $\begin{array}{l}\text { 11. Индекс постоянного } \\
\text { актива }\end{array}$ & 1,240 & 1,202 & 1,410 \\
\hline $\begin{array}{l}\text { 12. Трехкомпонент- } \\
\text { ный показатель типа } \\
\text { финансовой устой- } \\
\text { чивости }\end{array}$ & $\begin{array}{l}\Delta \mathrm{COC}<0 ; \\
\Delta \mathrm{CДИ}<0 ; \\
\Delta \mathrm{OИ}<0\end{array}$ & $\begin{array}{l}\Delta \mathrm{COC}<0 \\
\Delta \mathrm{CДИ}>0 \\
\Delta \mathrm{OИ}>0\end{array}$ & $\begin{array}{l}\Delta \mathrm{COC}<0 ; \\
\Delta \mathrm{CДИ}<0 ; \\
\Delta \mathrm{OИ}<0\end{array}$ & $\begin{array}{l}\text { 12. Коэффициент реальной } \\
\text { стоимости имущества }\end{array}$ & 0,890 & 0,866 & 0,898 \\
\hline $\begin{array}{l}\text { 13. Тип финансовой } \\
\text { устойчивости }\end{array}$ & $\begin{array}{l}\text { кризис- } \\
\text { ный }\end{array}$ & $\begin{array}{l}\text { нормаль- } \\
\text { ный }\end{array}$ & $\begin{array}{l}\text { кризис- } \\
\text { ный }\end{array}$ & & & & \\
\hline
\end{tabular}

Рассчитано автором на основе [2]. Calculated by the author based on [2] 
Анализ финансовой устойчивости АО «ФПК» с помощью относительных показателей показал средний уровень независимости от заёмных средств. Отметим незначительное ухудшение ситуации к 2020 г.: значение коэффициента автономии снизилось на 17,3 \%; высокий уровень финансирования за счёт устойчивых (используемых в деятельности более года) источников; отрицательное значение коэффициента маневренности говорит о распределении средств в медленно реализуемые активы (ообновление вагонного парка до 2025 г. в рамках договоров с ОАО «ТВ3») и о формировании оборотного капитала за счёт займов.

Действие 3. Расчёт стоимости чистых активов для оценки текущего финансового состояния (рис. 7-8).

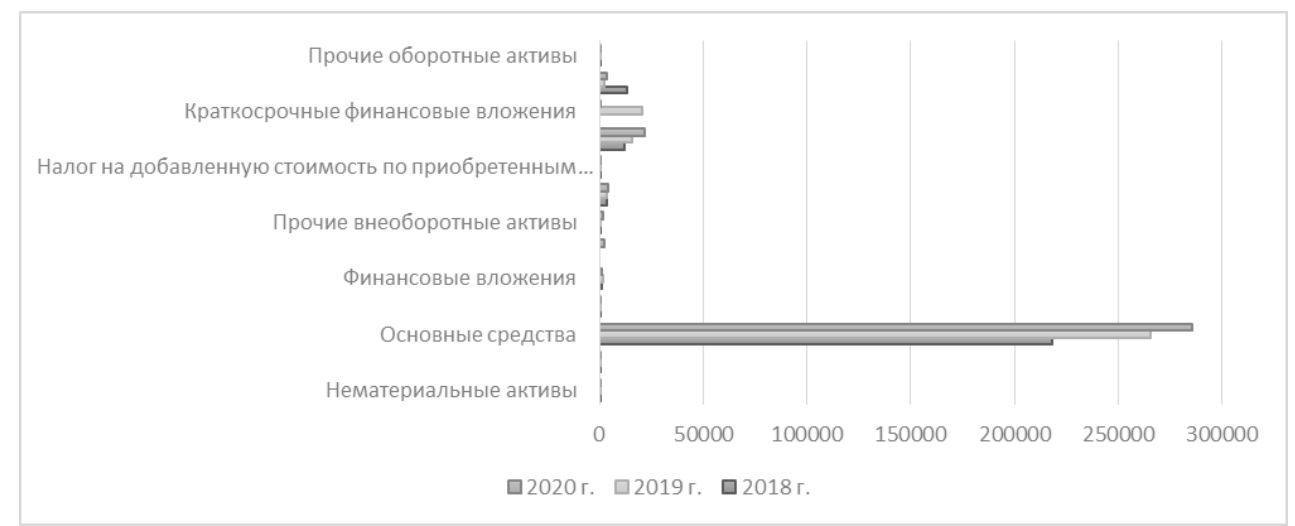

Puc. 7. Активы АО «ФПК» за 2018-2020 гг. Составлено автором на основе [2]

Fig. 7. Assets of JSC "FPC" for 2018-2020. Compiled by the author based on [2]

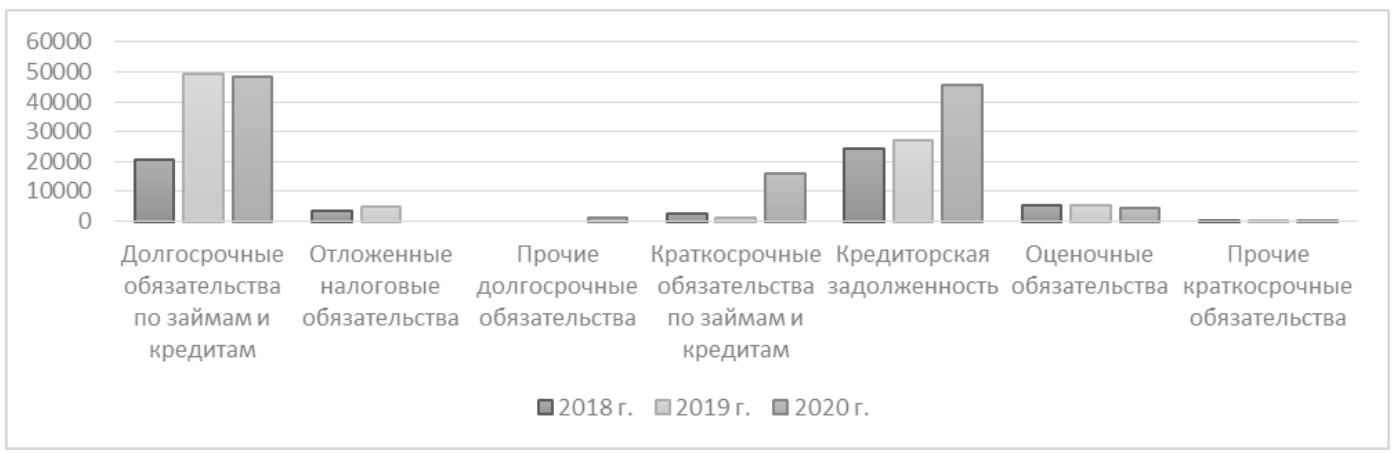

Рис. 8. Пассивы АО «ФПК» за 2018-2020 гг. Составлено автором на основе [2]

Fig. 8. Liabilities of JSC "FPC" for 2018-2020. Compiled by the author based on [2]

Согласно произведенным расчётам стоимость чистых активов в 2018 г. составила 194,0 млрд руб., в 2019 - 223,0 млрд руб., в 2020 г. - 206,6 млрд руб, т.е. наблюдается прирост более чем на 12 млрд руб. Однако в отдельные отчётные даты наблюдаются низкие значения величины чистых активов по сравнению с величи- 
ной уставного капитала. Это свидетельствует о наличии убытка и значительной вероятности банкротства. Тем не менее, динамика чистых активов положительна, в основном, за счёт значительной доли основных средств.

4. Предложены и обоснованы мероприятия, способствующие реализации стратегических ориентиров Компании. По итогам комплексного анализа деятельности и расчёта необходимых показателей оценки можно говорить о том, что одним из основных отраслевых рисков для АО «ФПК», влияющих на снижение эффективности дальнейшей деятельности, как на внутреннем рынке, так и на внешних рынках, является сокращение объёмов перевозочной деятельности. Пандемия Covid-19-20 - яркий пример этому, поскольку спад экономики и существующие ограничения повлекли за собой снижение транспортной мобильности населения и значительное сокращение пассажирооборота в дальнем следовании. В этой связи предложим ряд мероприятий, направленных на увеличение эффективности и финансовой устойчивости как собственно АО «ФПК», так и холдинга РЖД в целом (сформулированы автором на рис. 9) [6, с. 90].
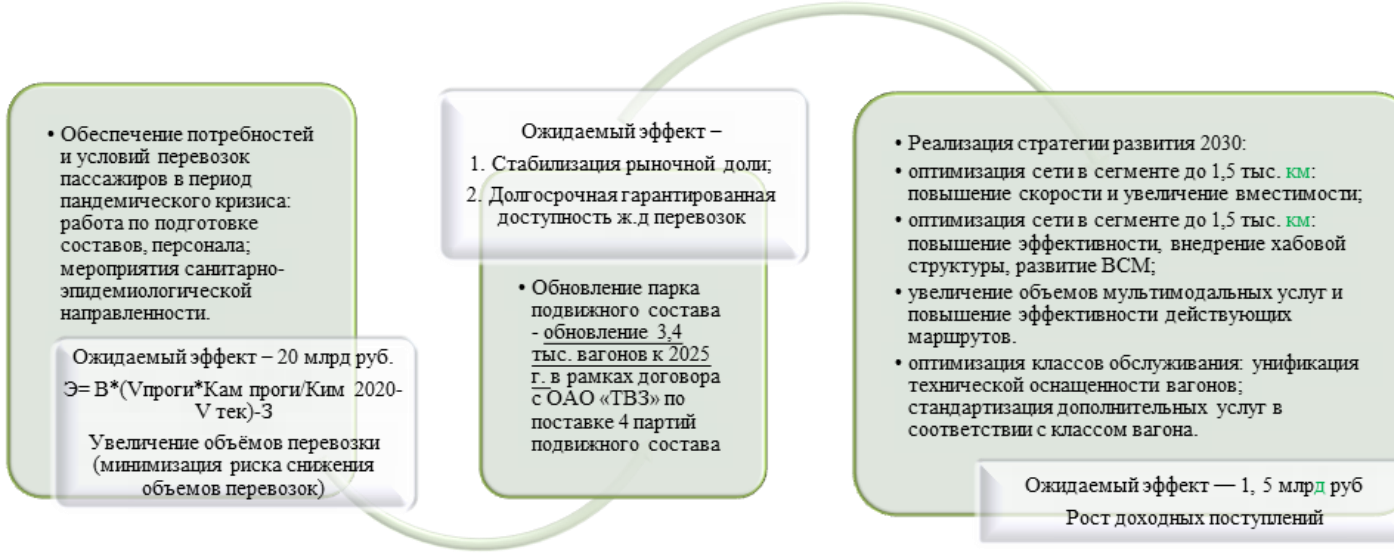

Puc. 9. Мероприятия, направленные на увеличение эффективности и финансовой устойчивости АО «ФПК».

Составлено автором на основе собственных выводов и заключений

Fig. 9. Measures aimed at increasing the efficiency and financial stability of JSC «FPC».

Compiled by the author based on her own findings and conclusions

3. Согласно результатам опроса пассажиров, организованного АО «ФПК», наиболее важным фактором влияния на транспортную подвижность является снижение платежеспособности пассажиров: 63\% пассажиров отмечают ухудшение материального положения в связи с пандемией. При этом 44\% респондентов отмечают, что сократят затраты на путешествия, 28\% переориентируются на поездки по России вместо заграничных, 17\% сократят продолжительность путешествия. Авиакомпании в условиях значительного снижения спроса в июне 2021 г. предпринимают меры по привлечению имеющегося на рынке пассажира 
путём демпинга цен. В качестве ответных мер АО «ФПК» вынуждено снижать доходную ставку. С учётом структуры перевозок АО «ФПК» снижение средней доходной ставки по итогам 2021 г. может составить 10-15\%. В результате отмеченных мер прогнозируемая до демпинга доходная ставка на 3 квартал 2021 г. в размере $103,5 \%$ в дерегулированном сегменте к уровню прошлого года может снизиться до уровня 93,2\%.

При реализации мероприятий по обеспечению прогнозируемого объёма перевозок (подготовка поездов, персонала, выполнение мероприятий санитарноэпидемиологической направленности) оценку эффекта по итогам перевозок пассажиров в летний период по сравнению с текущей ситуацией можно представить следующим образом (формула (1):

$$
\exists=\mathrm{B} \cdot\left(V_{\text {прогн }} \cdot \frac{\mathrm{K}_{\text {вм пропе }}}{\mathrm{K}_{\mathrm{BM} \text { 2020 }}}-V_{\text {тек }}\right)-3,
$$

где Э - дополнительные доходные поступления по итогам летних перевозок, млрд руб.;

В - выручка по перевозкам пассажиров в летний период 2020 г., млрд руб.;

$V_{\text {прогн }}-$ прогнозный объём перевозок, в долях к нормативному графику движения поездов;

$\mathrm{K}_{\text {вмпрогн }}-$ прогноз использования вместимости вагонов, в долях;

$\mathrm{K}_{\mathrm{Eм} 2020}$ - использование вместимости вагонов в летний период 2020 г., в долях;

$V_{\text {тек }}$ - объём перевозок пассажиров в мае 2021 г., в долях к аналогичному периоду прошлого года;

3 - дополнительные затраты на мероприятия по восстановлению объёмов перевозок, млрд руб.

$$
\ni=85,2 \cdot\left(0,632 \cdot \frac{0,55}{0,75}-0,218\right)-1,9=19,0 \text { млрд руб. }
$$

Одним из важнейших мероприятий, которое принесёт положительный эффект, является реализация долгосрочных программ развития, предусматривающих расширение географии перевозок, увеличение мобильности за счёт расширения сервисной линейки, модернизация инфраструктурных объектов, обновление подвижного состава (в рамках договора с ОАО «ТВЗ»).

Так, в случае назначения новых дневных поездов по маршрутам Москва Санкт-Петербург, Москва - Казань, Москва - Ульяновск, Москва - Вологда/Кострома, Москва - Рязань, Екатеринбург - Пермь, Екатеринбург - Тюмень, Хабаровск - Владивосток (в ежедневном обращении) дополнительные доходные поступления ОАО «РЖД» могут составить порядка 1,4 млрд руб. Их оценка осуществляется по формуле 2: 


$$
\exists=\mathrm{H}+\mathrm{T}_{\boldsymbol{y}}
$$

где Э - дополнительные доходные поступления в случае назначения новых дневных поездов, млрд руб.;

И - дополнительные поступления за предоставление услуг инфраструктуры (согласно действующим тарифам), млрд руб.;

$\mathrm{T}$ - дополнительные поступления за аренду локомотивов с экипажем (согласно действующим тарифам), млрд руб.

$$
\ni=0,996+0,364=1,4 \text { млрд руб. }
$$

В краткосрочной перспективе, помимо стандартных профилактических мер для обеспечения потребностей и условий перевозок пассажиров после прохождения пика пандемии, предлагается:

- совершенствование качества предоставляемой услуги по перевозке - модернизация и создание новых сервисов, пересмотр концепции общественного питания в вагонах, актуализаация маркетинговых проектов с учётом новых потребительских предпочтений;

- ведение диалога с органами исполнительной власти по вопросам возмещения потерь в доходах, образующихся в результате государственной тарификации перевозок отдельных категорий пассажиров;

- достижение индекса удовлетворённости пассажиров поездов дальнего следования в 2021 году более чем 4,5 балла.

Обобщая, обозначим, что комплексная оценка является одним из ключевых факторов для обоснования результата заёмщиками, для мониторинга и последующей оценки финансового состояния организации собственниками и бизнеспартнёрами, а также для государства при проведении надзорных и контрольных действий $[7$, с. 81$]$.

Отмечено, что, независимо от существующего множества методов и подходов комплексной финансовой оценки, отсутствует единообразная методика для организаций всех форм собственности, которая с большей долей вероятности прогнозировала бы состояние неплатёжеспособности в конкретный временной период. При этом комплесная оценка финансово-хозяйственной деятельности является необходимым условием при планировании и прогнозировании мероприятий, связанных с развитием в долгосрочной перспективе, поскольку принимает в расчёт основные показатели финансовой, хозяйственной и производственной деятельности организации. 


\section{Список источников}

1. Магомедова, В. Н. Зарубежные модели оценки финансового состояния и диагностики банкротства организации // Вестник современных исследований. 2018. - № 4. - С. 466-470.

2. Официальный сайт АО «Федеральная пассажирская компания»: годовой отчёт AO «ФПК» за 2020 г. - URL: https://fpc.ru/ru/7034 (дата обращения: 23.07.2021).

3. Волкова, Е. М. Развитие мультимодальных транспортных услуг в региональных пассажирских перевозках в долгосрочой перспективе // Тренды экономического развития транспортного комплекса России: форсайт, прогнозы и стратегии : сборник научных статей национальной научно-практической конференции. Москва : Российский университет транспорта (МИИТ), 2018. - С. 64-67.

4. Направления развития мультимодальных железнодорожно-автобусных пассажирских перевозок / А. Р. Ровинский, А. Р. Ухинова, А. В. Кубрак, И. М. Гулый // Актуальные вопросы экономики транспорта высоких скоростей : сборник научных статей национальной научно-практической конференции / под ред. Н. А. Журавлевой. - Санкт-Петербург : ООО «ИНСЭИ-оценка», 2019. - С. 283-292.

5. Никитина, К. С. Анализ финансовой устойчивости видов транспортной деятельности на территории Российской Федерации на основе модели Альтмана / К. С. Никитина, И. М. Гулый // Неделя науки СПбПУ : материалы научной конференции с международным участием. - Санкт-Петербург : Институт промышленного менеджмента, экономики и торговли, 2018. - С. 306-309.

6. Гулый, И. М. Инвестиционные проекты Холдинга ОАО «РЖД» в реализации стратегии пространственного развития Российской Федерации / Д. Холод, И. М. Гулый // Актуальные вопросы экономики транспорта высоких скоростей : сборник научных статей национальной научно-практической конференции / под ред. Н. А. Журавлевой. - Санкт-Петербург : ООО «ИНСЭИ-оценка», 2019. - С. 88-95.

7. Чеченова, Л. М. Методика комплексной оценки организации как инструмент планирования и прогнозирования её эффективного развития. - DOI 10.20295/2223-9987-2021-2-69-81 // Бюллетень результатов научных исследований. - 2021. - Вып. 2. - С. 69-81.

\section{Информация об авторе}

Л. М. Чеченова - кандидат экономических наук, доцент, доцент кафедры «Экономика транспорта», Петербургский государственный университет путей сообщения Императора Александра I. 


\section{References}

1. Magomedova V. N. Zarubezhnye modeli otsenki finansovogo sostoyaniya i diagnostiki bankrotstva organizatsii [Foreign models for assessing the financial condition and diagnosis of bankruptcy of the organization]. Vestnik sovremennykh issledovanii, 2018, vol. 4, pp. 466-470.

2. The official website of JSC "Federal passenger company": the annual report of JSC "FPC" for 2020. Available at: https://fpc.ru/ru/7034 (accessed 23 July 2021). (In Russian.)

3. Volkova E. M. Razvitie mul'timodal'nykh transportnykh uslug v regional'nykh passazhirskikh perevozkakh $\mathrm{v}$ dolgosrochoi perspektive [Development of multimodal transport services in regional passenger transport in the long-term perspective]. Trendy ekonomicheskogo razvitiya transportnogo kompleksa Rossii: forsait, prognozy $i$ strategii: sbornik nauchnykh statei natsional'noi nauchno-prakticheskoi konferentsii [Trends in the economic development of the transport complex of Russia: foresight, forecasts and strategies: collection of scientific articles of the national scientific-practical conference]. Moscow: Russian University of Transport (MIIT) Publ., 2018, pp. 64-67.

4. Rovinsky A. R., Ukhinova A. R., Kubrak A. V., Guly I. M. Napravleniya razvitiya mul'timodal'nykh zheleznodorozhno-avtobusnykh passazhirskikh perevozok [Directions of development of multimodal railway-bus passenger transportation]. In: Zhuravleva N. A. (ed.). Aktual'nye voprosy ekonomiki transporta vysokikh skorostei: sbornik nauchnykh statei natsional'noi nauchno-prakticheskoi konferentsii [Collection of scientific articles of the national scientific and practical conference "Actual issues of the economy of high-speed transport"]. St. Petersburg, 2019, pp. 283-292.

5. Nikitina K. S., Guly I. M. Analiz finansovoi ustoichivosti vidov transportnoi deyatel'nosti na territorii Rossiiskoi Federatsii na osnove modeli Al'tmana [Analysis of the financial stability of transport activities in the territory of the Russian Federation on the basis of the Altman model]. In: Nedelya nauki SPbPU: materialy nauchnoi konferentsii s mezhdunarodnym uchastiem [SPPU Science Week: materials of a scientific conference with international participation]. St. Petersburg: Institute of Industrial Management, Economics and Trade, 2018, pp. 306-309.

6. Kholod D., Guly I. M. Investitsionnye proekty Kholdinga OAO "RZhD" v realizatsii stra-tegii prostranstvennogo razvitiya Rossiiskoi Federatsii [Investment projects of the Russian Railways Holding Company in the implementation of the spatial development strategy of the Russian Federation]. In: Zhuravleva N. A. (ed.). Aktual'nye voprosy ekonomiki transporta vysokikh skorostei: sbornik nauchnykh statei natsional'noi nauchno-prakticheskoi konferentsii [Collection of scientific articles of the national scientific and practical conference "Actual issues of the economy of high-speed transport"]. St. Petersburg, 2019, pp. 88-95.

7. Chechenova L. M. Metodika kompleksnoi otsenki organizatsii kak instrument planirovaniya i prognozirovaniya ee effektivnogo razvitiya [Methodology of complex 
assessment of an organization as a tool for planning and forecasting its effective development]. Byulleten' rezul'tatov nauchnykh issledovanii, 2021, no 2, pp. 69-81. DOI: 10.20295/2223-9987-2021-2-69-81.

\section{Information about the author}

L. M. Chechenova - Candidate of Economic Sciens, Associate Professor, Associate Professor of the Department of "Transport Economics", St. Petersburg State University of Railways of Emperor Alexander I. 